\title{
Language Choice and Attitude of Maternal Communities in Semarang
}

\author{
Suharyo Suharyo ${ }^{1 *}$ and Subiantoro Subiantoro ${ }^{2,}$ \\ ${ }^{1}$ Indonesian Department,Faculty of Humanities, Diponegoro University, Semarang 50275, Indonesia \\ ${ }^{2}$ Semarang State University, Semarang, Indonesia
}

\begin{abstract}
This research focuses to describe the language choice and attitude of maternal communities in Semarang. To prove it, this research used 40 samples which are selected randomly. The data is collected through questionnaire, observation, and interview. The result showed that (a) the language choice and attitude of maternal communities is 5\% of them use Indonesian when speak to their husband, $45 \%$ use Javanese and 50\% use mixed language; (b) when they communicate with their children, $12,50 \%$ of them use Indonesian and Javanese and the $75 \%$ use mixed language; (c) they still expect Javanese subject to be well-taught at schools and homes $(87,50 \%)$ and at home only $(12,50 \%)$; (d) the Javanese language skill of the respondents is $12,50 \%$ very good, $67,50 \%$ good, and $20 \%$ less than good; and (e) the language attitude of the community reflects positive attitude $80 \%$ and negative attitude $20 \%$.
\end{abstract}

Keyword: choice; attitude; maternal community; Semarang

\section{Introduction}

Sociolinguistics exists due to language choice [1]. Language choice exists because of bilingualism or multilingualism. It also happens because of domain concept.[2] Among the domains, home domain is the most important of all considering the relationship with language choice and maintenance. It is because home domain is the benchmark as well as the last defense line of language maintenance.

Generally language attitude is a spontaneous reaction toward certain language. It can be classified into three aspects (a) cognitive (b) affective and (c) conative[3] . Besides, language attitude can also reflect whether a speech community has positive or negative attitude toward the existing language. Positive attitude is reflected through (a) language loyalty, (b) language pride, and (c) awareness of the language norms[4]. Feeling proud, for instance, because they still master the language skill and proud of being part of Javanese speech community[5]. Apart from that, it is also about the consideration of language norms in its usage. Meanwhile, negative attitude depicts contradictory symptoms which are (a) disloyalty, (b) shame, and (c) unawareness concerning language norms of mother tongue[6].

From the observation toward Javanese speech community, maternal community in particular, there are symptoms that (a) in maternal community, there is a language shift going on, from Javanese to Indonesian, (b) Indonesian starts to be spoken in home domain, (c) mixed language is more dominantly spoken, and (d) maternal community has negative attitude toward Javanese. [7]
Looking at those symptoms, this subject is very interesting to study. Is there any shift of attitude toward maternal community language? What is the language attitude of maternal community in Semarang toward Javanese, Indonesian, and mixed language? Is the attitude positive or negative toward Javanese?

\section{Method}

The problem in this research is language choice and attitude of maternal community who live in Semarang. This research aims to describe language choice and attitude of maternal community who live in Semarang city.The population of the data is maternal community who live in Semarang with several criteria: under and/or above 30 years of age, living in the area of Semarang city, Javanese, and having child(ren).

The sample in this research is collected using purposive random sampling based on the population characters. There are total 40 samples. The data is collected by questionnaire technique. The questionnaire contains respondent identity, the respondents' language choice and attitude toward Javanese, Indonesian, and mixed language. Apart from questionnaire and data interpretation, the method used in this research is nonparticipatory observation and interview.

The data is analyzed using simple quantitative/percentage technique and data interpretation. For example, 20 respondents speak mixed language daily at home. The calculation will be $(20 / 40) 100 \%=50 \%$. From this result, the next step is interpretation. It can be interpreted that maternal community in Semarang is experiencing shift in the case of their language attitude. 


\section{Result and Discussion}

From the total 40 respondents whose data has been collected in this research, the result showed that:

1). The everyday language of the respondents in their home domain, there are 2 respondents $(5 \%)$ who speaks Indonesian, 18 respondents $(45.45 \%)$ who speaks Javanese, and the rest (50\%) who speak mixed language. 2 ). The language spoken by maternal community when communicating with their child(ren), 5 respondents $(12.50 \%)$ speaks Javanese, and 30 respondents (75\%) speak mixed language.

3) The language attitude of maternal community about the importance of Javanese to be taught, 35 respondents $(87.50 \%)$ consider that Javanese need to be taught both at home and school, and 5 respondents $(12.50 \%)$ consider that Javanese only need to be taught at home only.

4). The reasons about the necessity of Javanese to be taught at home or school are (1) in order to prevent Javanese from extinction, (2) to maintain the Javanese identity, (3) to keep their language, (4) to cherish Javanese language and culture, (5) to make their children respect their elderly, (6) to preserve the language, (7) the love for Javanese language, (8) the lesser usage of Javanese, and (9) to make Javanese not to be forgotten.

5). Regarding the Javanese language skill, 5 respondents $(12.5 \%)$ are very good, 27 respondents $(67.50 \%)$ are good, and 8 respondents $(20 \%)$ are less than good.

$6)$. The reasons why maternal community speak Indonesian are (1) Indonesian is considered more practical and easier $(47.50 \%)$, (2) Indonesian is the language used by wider society circle $(32.50 \%)$, and (3) Indonesian is the national language (20\%).

7). The reasons of Javanese usage by maternal community are (1) Javanese is the language of their predecessor $(45.45 \%)$, (2) to cherish and maintain Javanese language (10\%), and (3) as the medium of character building.

8). Respondents who speak mixed language also have their reasons which are (1) they live in Javanese society $(12.50 \%),(2)$ in order to skillfully speak both language (Javanese and Indonesian) (75\%), and the rest did not give any reason $(12.50 \%)$.

The result of the research showed the diglossia "leak" even though the rate is relatively insignificant (5\%). Besides, the language attitude of the maternal community is shifting. This is reflected through their choice of language by shifting between Javanese and Indonesian when communicating with their husband (50\%), although there are some $(45.45 \%)$ who still completely speak Javanese. Their "two-timing" attitude is also seen through their mixed language choice when communicating with their children for $30.75 \%$. Meanwhile the ones who either use Javanese or Indonesian is each $5 \%$ only.

However, the interesting part is that maternal community expects Javanese to be taught at school and home $(87.50 \%)$. This is in line with their "torn" language attitude. In other words, maternal community wants to maintain Javanese in its cognitive case, not its praxis/conative case.

Generally $80 \%$ of them have positive attitude while $20 \%$ have negative attitude.

\section{Conclusion}

In number, the Javanese speaker in home domain is relatively high (45.45\%) while mixed language usage is by $50 \%$. The Indonesian speakers are $5 \%$ only. The language attitude of maternal community in Semarang showed the relatively significant symptoms of attitude shifting) rate by $50 \%$ when communicating with their husbands and $30.75 \%$ when communicating with their children.

Even though the diglossia 'leak' rate is relatively small by $5 \%$, it does happen because Indonesian has been used in home domain. The reasons are in the following: (a) it is regarded as national language, (b) it is used in wider social circle, (c) because of its practicality; on the other hand the reasons why Javanese are used are (a) to maintain Javanese language and culture, (b) to prevent Javanese from being extinct, and (c) as the medium of character building for their children. Maternal community in Semarang still expects Javanese to be taught at home and at school because (a) in order to prevent Javanese from extinction, (as the Javanese identity marker, (c) to cherish Javanese language and culture, (d) to bring respect to elderly, and (e) the lesser usage of Javanese in both home and social domain. An interesting finding, urban mothers in using language consider aspects of environmental conservation such as planting attitudes, recycling waste, separating organic and non-organic waste.

\section{References}

1. R. Fasold, Introduction to Sociolinguistics. Blackwell, Oxford (1984)

2. J. Fishman, Language in Sociocultural Change. Stanford University Press, Stanford. (1972).

3. J.C Richards, Platt, John Talbot. , and Weber, Heidi. Longman Dictionary of Applied Linguistics Harlow, Essex. (1985).

4. A.W. Wicker, Journal of Social Issues, 25, 41-78. Attitudes versus actions: The relationship between verbal and overt behavioral responses to attitude objects. (1982).

5. H. Kridalaksana, KamusLinguistik. Gramedia Pustaka. Jakarta. (2001).

6. A. H. Eagly, \& Chaiken, S. The Psychology of Attitudes. Harcourt Brace Jovanovich College Publishers, Orlando. (1993).

7. P.L Garvin, and Mathiot, Madeleine. The Urbanization of The Guarani Language: A Problem In Language And Culture. edited Fishman, Joshua A. In Readings in the Sociology of Language. Boston: De Gruyter, Berlin. (1968) 